\title{
David Jacoby
}

\section{The Jews in Byzantium and the Eastern Mediterranean: Economic Activities from the Thirteenth to the Mid-Fifteenth Century"}

The geographic range of this study requires a short explanation. Byzantium suffered successive territorial losses in the period following the Fourth Crusade (1202-1204), and before its fall in 1453 it was more or less limited to Constantinople and the Peloponnesus. The Latin conquests of the early thirteenth century were followed by the restructuring of commercial networks and a partial re-orientation in the flow of goods in the eastern Mediterranean, which deeply affected Byzantium in the long-run ${ }^{1}$. The investigation of the late Byzantine economy, therefore, cannot be limited to the shrinking territorial framework of the Empire. It must be examined within the context of the broader region within which that economy integrated, primarily in relation to Latin Romania, the former Byzantine lands occupied by the Latins after the Fourth Crusade.

This approach is also indispensable with respect to the Jews in the late Empire for yet another reason, namely, the paucity and nature of the sources bearing on their economic activities. I have recently traced the continuous presence of the

* The following abbreviations are used below: ASV = Archivio di Stato di Venezia, cited for unpublished documents; Badoer $=$ Umberto Dorini e Tommaso Bertelè (eds.), Il libro dei conti di Giacomo Badoer (Costantinopoli, 1436-1440) (Il Nuovo Ramusio III Roma 1956); BB = Raimondo Morozzo della Rocca (ed.), Benvenuto de Brixano, notaio in Candia (1301-1302) (Venezia 1950); LM = Mario Chiaudano e Antonino Lombardo (eds.), Leonardo Marcello, notaio in Candia, 12781281 (Venezia 1960); PP = Salvatore Carbone (ed.), Pietro Pizolo, notaio in Candia (1300, 13041305) (Venezia 1978-1985); PS = Antonino Lombardo (ed.), Imbreviature di Pietro Scardon (1271) (Documenti della colonia veneziana di Creta I, Torino 1942); Taqqanoth = Elias S. Artom et Humbertus M. D. Cassuto (eds.), Taqqanoth Qandya ve-Zichronoteha (Statuta Iudaeorum Candiae eorumque memorabilia) (Jerusalem 1943) [Hebrew]; ZF = Antonino Lombardo (ed.), Zaccaria de Fredo, notaio in Candia (1352-1357) (Venezia 1968). BB, LM, PP and ZF have been edited by the Comitato per la pubblicazione delle Fonti relative alla Storia di Venezia, in the series Fonti per la storia di Venezia, Sez. III - Archivi notarili. For the sake of uniformity known Jewish names cited in documents are reproduced below in their Hebrew version.

${ }^{1}$ David Jacoby, Changing Economic Patterns in Latin Romania: The Impact of the West, in: Angeliki E. Laiou and Roy Parviz Mottahedeh (eds.), The Crusades from the Perspective of Byzantium and the Muslim World (Washington, D.C. 2001) 220-229, repr. in David Jacoby, Commercial Exchange across the Mediterranean: Byzantium, the Crusader Levant, Egypt and Italy (Aldershot 2005) no. IX. 
Jewish community in Thessalonica from the twelfth to the second half of the fifteenth century, yet without finding any indication regarding the economic occupations in which its members engaged ${ }^{2}$. The sources illustrating the strong impact of western maritime powers in the eastern Mediterranean provide the bulk of evidence regarding the Jews of Byzantium and of Latin Romania in the period covered here. Among these sources notarial charters, of primary importance, are particularly abundant for Crete, ruled by Venice from the early thirteenth century onward, and somewhat less for Chios, occupied by the Genoese from 1346 to 1566. Yet for many other localities the sources offer at best only scattered and isolated data regarding individual Jews and their economic pursuits, or else clusters of relevant information covering short periods. Therefore, any attempt to reconstruct the role of the Jews in the economy of the eastern Mediterranean and to assess its degree of continuity also requires an occasional return to an earlier period and reliance upon circumstantial evidence.

With few exceptions Jews were an exclusively urban element in the eastern Mediterranean of the late Middle Ages ${ }^{3}$. Their economic activities primarily took place within cities or in relation to them, even if they held or owned rural property ${ }^{4}$. These activities, as in other regions, displayed some distinctive features. The production, marketing and consumption of specific commodities among Jews were governed by religious precepts and by strict control and, therefore, were carried out under particular conditions differing from those customary in Christian or Muslim societies. Jews maintained an internal economic network, specific to their communities and exclusively geared toward Jewish customers. This network warrants a separate treatment in view of its economic importance.

The choice and slaughter of animals for meat consumption according to ritual requirements was generally performed in cities. On the other hand, as urban residents Jews depended upon farmers for the supply of grapes and milk, respectively for the production of wine and the consumption of milk, butter and cheese. We have no information regarding the internal Jewish network in Byzantium, whether in the centuries preceding the Fourth Crusade or following it. Yet the evidence regarding kasher wine and cheese produced in Venetian Crete, apparently more abundant than for any other group of medieval Jewish communities, offers an insight into its nature and operation. The set of ordinances issued in 1228 by the Jewish leaders in Crete points to well-structured communities and implies the existence of a Jewish economic network in the island in the preceding Byzantine period $^{5}$.

In Venetian Crete the purchase of agricultural and pastoral products, mainly wine, cheese and grain, was often tied to advance payments for the delivery of an

2 Except in the 1160s. See David Jacoby, Foreigners and the Urban Economy in Thessalonike, c. 1150 - c. 1430, in: Dumbarton Oaks Papers 57 (2003) 123-129.

3 A Jew living in the Cretan village of Pala in 1352 was clearly an exception: ZF no. 43.

${ }^{4}$ On which see below, pp. 45-46.

5 Taqqanoth 3-6, no. 2. 
agreed quantity of produce at a specific date or within a specific period. This sale credit system, with its concealed loans, is illustrated by numerous contracts, the exact terms of which widely varied. It was presumably far more common in the Venetian period than in the preceding Byzantine era ${ }^{6}$. For Jews sale credit was not just an option. It was indispensable to ensure constant and close supervision according to rabbinical precepts over wine and cheese directly ordered from the producer.

Kasher wine was in constant demand for Jewish ritual functions, yet was also purchased as beverage. In Crete Jews used sale credit before the grape harvest to ensure the delivery of wine fit for consumption. By contracts of May and August 1271 a Greek woman residing in Candia, the capital of Venetian Crete, promised to deliver a total of 175 mistati or 2,252 liters wine from her vineyard in the village of Catalagari to a Jew of the city ${ }^{7}$. Jewish seasonal workers were sent to the countryside to clean the wine press, wine cellar, vats and casks, press the grapes, and supervise the transportation of the must or the wine to Candia ${ }^{8}$. In 1357 the wealthy Moses son of Yehudah instructed that grapes sufficient for the production of 150 mistati or 1,930 liters wine be brought to his house in order to have them pressed in the city 9 .

Ever larger volumes of cheese were being traded over long distances in the Mediterranean from the eleventh century onward, as illustrated by Byzantine, Arabic, Jewish and western sources. Exports of Cretan cheese to Constantinople are attested from the 1020s and to Alexandria from the 1060s. An eleventh or twelfthcentury Jewish letter written in Alexandria apparently deals with the import of Cretan cheese. By the second half of the twelfth century Venetian involvement in the import of high-grade Cretan cheese to Constantinople was so extensive that the Venetian quarter had become the major market for that commodity in the city $^{10}$. We may safely assume, therefore, that kasher cheese produced in the island also reached Constantinople and other Byzantine cities in that period.

All stages of production and distribution of kasher cheese were conducted under close supervision, as for wine. Various precepts applied to milking, the use of rennet from a ritually slaughtered animal to curdle the milk, as well as to the processing, storage, transportation and marketing of the cheese. Religious consid-

${ }^{6}$ Jacoby, Changing Economic Patterns 218, on the background and effects of that system.

7 PS nos. 319, 429. The botte of Candia, also used for shipments to Constantinople and Alexandria, contained 540. 70 liters equivalent to 42 mistati: see Ugo Tucci, La botte veneziana, in: Studi veneziani 9 (1967) 213-217, esp. 215-216. It follows that the mistatus held 12.87 liters.

8 Taqqanoth 22-25, no. 33 .

9 ZF no. 93.

10 David Jacoby, Byzantine Crete in the Navigation and Trade Networks of Venice and Genoa, in: Laura Balletto (ed.), Oriente e Occidente tra medioevo ed età moderna. Studi in onore di Geo Pistarino (Università degli Studi di Genova, Sede di Acqui Terme, Collana di Fonti e Studi 1/1, Acqui Terme 1997) 519-523, 525-529, 535-536, repr. in David Jacoby, Byzantium, Latin Romania and the Mediterranean (Aldershot 2001) no.II. For the Jewish letter, see Sblomo D. Goitein, A Mediterranean Society. The Jewish Communities of the Arab World as Portrayed in the Documents of the Cairo Geniza, vol. I (Berkeley and Los Angeles 1967-1993) 429, n. 66. 
erations, in addition to economic incentives, prompted some Jews to commission cheese directly from producers rather than purchase it from Jewish merchants. In a notarial contract of 1304, a Jewess of Candia undertook to send a Jewish worker to produce $68.7 \mathrm{~kg}$ ripe Jewish cheese she had ordered from a Greek living at Belvedere, in southern Crete ${ }^{11}$. The latter promised transportation and delivery of the cheese at the market place of Candia ${ }^{12}$. In 1301 a Greek of the Cretan city of Canea undertook to bring to the home of a resident of Candia 180 Cretan gross pounds or some $94 \mathrm{~kg}$ Jewish cheese ${ }^{13}$. Jews buying cheese molds from merchants made sure that they had been properly produced, stamped and handled ${ }^{14}$.

Laxity in supervision induced the leaders of the Jewish community of Candia to state in greater detail the rules to be applied to the production, transportation and marketing of Jewish products. In 1363 they issued an ordinance regarding kasher wine, incidentally allowing the sale of improperly handled wine to Christians ${ }^{15}$. They also prohibited at several occasions the purchase of milk, butter and cheese they considered unfit for Jewish consumption. In 1363 they dealt with cheese bought by Jews of Castelnuovo in southern Crete from local Christian producers and marketed as kasher produce ${ }^{16}$.

Some contracts between Cretan Jews and non-Jews provided for the delivery of rather small amounts of wine or cheese. In 1301 a Jew ordered 34 mistati or 437 liters must ${ }^{17}$. A Greek peasant promised the delivery of some $52 \mathrm{~kg}$ cheese in April 1272 to Salomon son of Shabbetai ${ }^{18}$. As in the case of the Jewess mentioned earlier, these consignments were intended for private consumption or for local retail trade. Yet other transactions involved Jewish merchants acting as entrepreneurs, who commissioned the production of large volumes of wine and cheese that they handled in bulk, selling the produce to local retailers or other wholesale merchants or else exporting it.

11 The quantity mentioned was $2 / 15$ of one milliarium of Candia. The latter weighed 1,100 Venetian libre grosse of $0.476 \mathrm{~kg}$, hence $523 \mathrm{~kg}$. For this ratio, see Francesco Balducci Pegolotti, La pratica della mercatura, ed. by Allan Evans (Cambridge, Mass. 1936) 106. The gross pound of Candia or $1 / 1000$ of the milliarium thus weighed $0.523 \mathrm{~kg}$.

12 PP no. 850: de bono caseo Cretensi bene conducto [sic for condicto] et sasionato indaico (...) Et tu debes mittere Iudeum ad faciendum ipsum caseum. On this 'hard' cheese, which could travel over long distances, see David Jacoby, Cretan Cheese: A Neglected Aspect of Venetian Medieval Trade, in: Ellen E. Kittel and Thomas F. Madden (eds.), Medieval and Renaissance Venice (Urbana and Chicago 1999) 50-51, repr. in Jacoby, Commercial Exchange no. VIII. A Jewish ordinance issued in Candia in 1363 refers to Jewish workers 'freezing' the cheese in the rennet: Taqqanoth 27, no. 37, lines 17-18. The rennet is also mentioned ibid. 55, no. 55, lines 21-22.

13 BB no. 420.

14 A stamp is mentioned in 1399: Taqqanoth 55, no. 55, line 38, and see commentary 54 . On stamped cheese molds in Egypt, see Goitein, A Mediterranean Society, vol.IV, 251 and 444, n. 188.

15 See above, n. 15 .

16 On milk, butter and cheese in 1363 : Taqqanoth $27-28$, no. 37, and 52-53, no. 53, a case of unaccompanied milk sold by a Christian to Jewish customers; in 1399: ibid. 54-56, no. 55.

17 BB no. 50.

18 PS no. 438. Shabbetai appears as Sambatus in Venetian notarial documents. 
We have already noted two contracts for some 2,000 liters and more wine ${ }^{19}$. Within less than four months in 1280-1281 Jeremiah Nomico made advance purchases of 600 mistati or 7,722 liters of Jewish wine, sufficient for the yearly consumption of at least 25 people ${ }^{20}$. As we shall see below, some Jews exported even larger volumes. Wine production in Crete was furthered by a substantial expansion of vineyards from the fourteenth century onward in response to a growing foreign demand, especially for high-grade brands ${ }^{21}$. Similarly, there was an increasing Jewish demand for Cretan wine, both locally and abroad, as illustrated by later documents adduced below.

As for wine, some Jewish entrepreneurs handled large volumes of cheese. A Jew of Candia, Shabbetai son of Moses, ordered in three contracts concluded from April to August 1271 a total of $628 \mathrm{~kg}$ cheese $\mathrm{e}^{22}$. Moses the dyer was expecting 784 $\mathrm{kg}$, partly in April and the rest in May 1272 at the latest ${ }^{23}$. Two Jews of Rethymno, Salomon son of Lazar and Moses Capsali, made considerable advance purchases of cheese before 1402, although such purchases with or without payments had been prohibited in 1393 since they led to the indebtedness and flight of peasants and herd owners ${ }^{24}$. The two Jews were heavily fined in 1402, respectively 7,219 and 3,974 hyperpers, sums that imply large amounts of cheese obviously intended for export, in the first case well above 100 metric tons ${ }^{25}$.

Kasher cheese and wine produced in Venetian Crete were widely distributed throughout the eastern Mediterranean. The earliest explicit reference in this respect appears in a contract concluded in 1300 between two Jews of Candia for trade in kosher cheese per terram et per aquam. Incidentally, the contract also refers to the

19 See above, p. 27.

20 LM nos. 323, 452. In the fourteenth century, the average yearly consumption of wine in Venice, Genoa and Florence was between 250 and 300 liters: John Day, Prix agricoles en Méditerranée à la

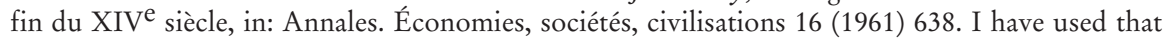
average here in the absence of a similar study for the eastern Mediterranean.

21 Jacoby, Changing Economic Patterns 219.

22 PS nos. 218, 280, 436.

23 PS nos. 421 and 448. Prices varied between 12 and 16 Cretan hyperpers per milliarium of Candia.

24 Prohibition of 1393: Hippolyte Noiret, Documents inédits pour servir à l'histoire de la domination vénitienne en Crète de 1380 à 1485 (Paris 1892) 55. The Jews got hold of the herds belonging to defaulting debtors: see ibid., 59-60. The officials who condemned the two Jews and the fines are mentioned in a decision of 1403 by which the doge's council overturned the verdict: ed. by Freddy Thiriet, Délibérations des assemblées vénitiennes concernant la Romanie, vol. II (Paris 1966-1971) 308, no. 1042. These officials had left Venice in 1402: Constantin N. Sathas, Documents inédits relatifs à l'histoire de la Grèce au Moyen Age, vol.II (Paris 1880-1900) 56-59.

25 The fine comprised the value of the cheese and, in addition, 50 hyperpers for each purchase. A purely hypothetical calculation illustrates the magnitude of the business deals. If in the first case we assume fifty purchases entailing fines $(50 \times 50$ hyperpers $=2,500)$, the remaining 4720 hyperpers would have covered purchases over several years totaling 277 milliaria or 144.871 metric tons at the rate of 17 hyperpers per milliarium. For the sake of comparison, in 1300 the Venetian Andrea Corner ordered a total of 30 milliaria or 15.690 metric tons at the same rate from two merchants, one in Canea and the other in Candia, obviously for export, the total cost reaching 510 hyperpers: PP nos. 170, 332. 
shipping of ritual ram horns or shofars, clearly intended for export ${ }^{26}$. In 1352 a Jew of Candia purchased the fourth part of a griparia, a small ship, which regularly sailed from the Cretan port to Famagusta in Cyprus, Syria, Cilician Armenia, Rhodes and Alexandria. The Jewish merchant obtained a maritime loan from the Greek partner, and enjoyed free transportation and board. The reimbursement of the loan was to take place within one month after arrival at Famagusta or Rhodes ${ }^{27}$. The whole business arrangement was clearly related to the shipping of Jewish commodities. This was presumably also the case in 1411, when a Jew of Candia sailing to Rhodes suffered losses inflicted by a Sicilian merchant ${ }^{28}$.

Jewish wine and cheese were also shipped from Crete to more distant ports. They were most likely included among the goods belonging to a Venetian Jew yet carried by a Genoese ship, which were confiscated some time before April 1343 by the authorities of Pera, the Genoese suburb of Constantinople ${ }^{29}$. In 1370 a Jew of Candia concluded a contract with a local Greek for the transportation of ten casks containing 5,407 liters wine as well as cheese to Constantinople ${ }^{30}$. In 1403 or 1404 the Genoese authorities in Pera seized 23 casks holding 12,436 liters kasher Cretan wine $^{31}$. Lazar son of Isaac de Alemania shipped wine from Candia to the Byzantine capital in $1418^{32}$.

As attested in 1320, Venetian merchants went from Constantinople to the countryside at the time of the grape gathering to buy must ${ }^{33}$. There is good reason to believe that some Jews of Constantinople acted similarly and proceeded like Cretan Jews to ensure their basic supply of kasher wine. The Jewish wine from Crete was nevertheless competitive, as suggested by its import. It was sold in the Venetian quarter of Constantinople, as well as in the Genoese quarter, as implied by its occasional confiscation in Pera. The Byzantine authorities strongly opposed its sale to Byzantine Jews, like that of Cretan non-kasher wine to other imperial

26 PP no. 554, modeled after the collegancia contract no.553. On that type of contract, see below, p. 44. The formula per terram et per aquam sometimes covered trade in Crete and along its coast, as explicitly stated in BB nos. 237 and 421.

27 ZF nos. 61, 66, 71, 72. That sailing to Egyptian ports was common is implied by a clause prohibiting it on that specific occasion: ibid. no.71.

28 Noiret, Documents 211.

29 ASV, Senato, Misti, reg. 21, fol. 24v-25r.

30 Silvano Borsari, Ricchi e poveri nelle communità ebraiche di Candia e Negroponte (secc. XIIIXIV), in: Chryssa A. Maltezou (ed.), Plousioi kai ftochoi sten kononia tes ellenolatinikes Anatoles (= Ricchi e poveri nella società dell'Oriente grecolatino) (Biblioteca dell'Istituto ellenico di Studi bizantini e postbizantini di Venezia 19, Venezia 1998) 216, 217.

31 Noiret, Documents 179-180. The case, discussed in 1406, occurred while Tommaso Mocenigo was duke of Crete, an office to which he had been elected in 1403: ibid. 147 and n.1.

32 Nicolas Iorga, Documents concernant les Grecs et les affaires d'Orient tirés des registres des notaires de Crète, in: Revue historique du sud-est européen 14 (1937) 93.

33 Georg Martin Thomas (ed.), Diplomatarium veneto-levantinum, vol. I (Venetiis 1880-1899) 164 lines 2-3 from below; see also David Jacoby, Les Vénitiens naturalisés dans l'Empire byzantin: un aspect de l'expansion de Venise en Romanie du XIII ${ }^{\mathrm{e}}$ au milieu du $\mathrm{XV}^{\mathrm{e}}$ siècle, in: Travaux et mémoires 8 (1981) 224-225, repr. in David Jacoby, Studies on the Crusader States and on Venetian Expansion (Northampton 1989) no. IX. 
subjects, since Venetian citizens and subjects enjoyed full tax exemption ${ }^{34}$. Some time before 1450 they established a special office, called scribania vegetum Judeorum Venetorum, which collected a tax of one half of a hyperper on each imported cask. Emperor Constantine XI promised to abolish the tax when Venice protested against this infringement of its privileges ${ }^{35}$.

Jews were legally barred from permanently residing in Venice until 1513, except for the years 1382-1397. Some Jews nevertheless lived in the city in the fourteenth century, clearly with the knowledge of the Venetian authorities ${ }^{36}$. The Cretan shipments of kasher wine and cheese were intended for local Jews, as well as for the Jewish communities in the neighboring continental territories of northeastern Italy. However, Alexandria appears to have become the main foreign market for these commodities in the fourteenth century. Wine was in high demand in Egypt, in which it was not always easily available due to restrictions imposed by the Muslim authorities ${ }^{37}$. Liachus or Elijah Capsali, a Cretan Jew from Rethymno apparently established in Alexandria, traded in kasher Cretan wine on a very large scale. In April 1421, he imported 70 casks containing 37,849 liters ${ }^{38}$. In the following year he concluded in Alexandria an agreement for the transportation of 50 or 60 casks of Jewish wine as well as cheese from Rethymno to Alexandria on board a small vessel belonging to a resident of his home city ${ }^{39}$. He had hired or acquired in Alexandria a warehouse that also served as tavern to store kasher wine and engage in its retail trade, handled by a Jewish servant ${ }^{40}$. In 1428 other Cretan Jews imported Jewish wine that was to be delivered in Alexandria to two Jewish agents of a Jew of Rethymno or sold in retail, ad minutum sive ad spinam ${ }^{41}$.

Kasher cheese and wine were exclusively handled by Jews within a closed Jewish production, distribution and marketing network requiring and affording constant

34 Ibid. 225-226.

35 Thomas, Diplomatarium, vol. II, 379-380.

${ }^{6}$ David Jacoby, Les Juifs à Venise du XIV e au milieu du XVI ${ }^{\mathrm{e}}$ siècle, in: Hans-Georg Beck, Manoussos Manoussacas, Agostino Pertusi (eds.), Venezia, centro di mediazione tra Oriente e Occidente (secoli XV-XVI): aspetti e problemi (Atti del II Convegno internazionale di storia della civiltà veneziana, Venezia 1973) vol. I (Firenze 1977) 163-216, repr. in David Jacoby, Recherches sur la Méditerranée orientale du XII ${ }^{\mathrm{e}}$ au XV ${ }^{\mathrm{e}}$ siècle. Peuples, sociétés, économies (London 1979) no.VIII; David Jacoby, I Greci ed altre comunità tra Venezia e oltremare, in: Maria Francesca Tiepolo ed Eurigio Tonetti (eds.), I Greci a Venezia (Atti del Convegno Internazionale di Studio, Venezia, 5-7 novembre 1998) (Istituto Veneto di Scienze, Lettere ed Arti, Venezia 2002) 67-79.

37 For instance in 1428: Eliyabu Ashtor, New Data for the History of Levantine Jewries in the Fifteenth Century, in: Bulletin of the Institute of Jewish Studies 3 (1975) 78-79, repr. in Eliyahu Ashtor, The Jews and the Mediterranean Economy, $10^{\text {th }}-15^{\text {th }}$ Centuries (London 1983) no. VIII.

38 Ed. by Ashtor, New Data 93-94, no. I.

39 Ed. by Charles Verlinden, Marchands chrétiens et juifs dans l'Etat mamelouk au début du XV siècle d'après un notaire vénitien, in: Bulletin de l'Institut historique belge de Rome 51 (1981) 72-73. On the technical expressions de firmo and de respectu, see Ashtor, New Data 78, n.2.

40 Ed. by Ashtor, New Data 95-96, doc II, and see also 77-78; Eliyahu Ashtor, Ebrei cittadini di Venezia?, in: Studi veneziani 17-18 (1975-76) 151-152.

${ }^{41}$ ASV, Cancellaria inferiore, Notai, b. 211, Nicolo Turiano, IV, fol. 50v-51r. Ashtor, New Data 78-79, failed to note the retail trade. On Liachus Capsali and other Jewish traders in Egypt in the 1420s, see ibid. 75-79; Ashtor, Ebrei cittadini 147-148, 150. 
supervision. Since Jews accompanied these commodities on land and sea, it is hardly surprising that they took advantage of their business trips and connections to extend the range of their transactions to unsold kasher surpluses, products rendered unfit for Jewish consumption, and non-kasher wine and cheese. This offshoot of the internal Jewish traffic further promoted the integration of Jewish merchants within the broader trade patterns of the eastern Mediterranean, beyond their use of land and maritime transportation provided by Christians and Muslims.

The sale of wine rendered unfit for Jewish consumption was permitted by the leaders of the Jewish community of Candia ${ }^{42}$. On 2 August 1280 the Jew Lignaco concluded an agreement with two Christian residents of Candia by which he offered them 400 mistati or 5,148 liters of wine, in return for the same quantity of must delivered at his home in the following month from the vineyard cultivated by one of the two Christians. The must would have obviously been kasher. At first glance the transaction appears to be an exchange, yet in fact it was a loan for somewhat more than a month, as explicitly stated in the contract. It is likely that the concealed interest paid by the Christian traders consisted in transportation costs, which they covered both for the wine they received and the one they were to deliver ${ }^{43}$. In the first half of the fifteenth century some Cretan Jewish merchants also dealt with wine unfit for Jewish consumption in Alexandria. In 1422 Elijah Capsali from Rethymno sold 60 casks containing 32,442 liters wine imported from his home city to the consul of Naples and to two Venetian tavern-keepers ${ }^{44}$.

Similar transactions are attested for cheese. In October 1280 Shabbetai Callamiti of Candia transferred some 80 milliaria or around 38 metric tons cheese to a Greek of Belvedere, as a loan in kind until Lent of the following year ${ }^{45}$. We have already noted the large volume of cheese handled by Salomon son of Lazar. His business was clearly not limited to kasher cheese. Around 1382 he obtained for himself and his descendants permission to maintain shops for retail trade outside the Jewish quarter of Rethymno. The grant was revoked in 1412, when prominent Latin residents of the city complained that the Jews dominated the local retail market. It was decided, therefore, that in Rethymno, as in Candia and Canea, the Jews should have shops exclusively within the boundaries of their quarters. However, they were allowed to maintain storehouses outside their quarter, in view of the large volume of cheese, wine and other commodities they handled ${ }^{46}$.

\footnotetext{
42 See above, p. 28.

43 LM no.156. Lignacus concluded a similar deal with another Christian in March 1281: ibid. no. 535 .

${ }^{44}$ Ed. by Ashtor, New Data 94-97, no. II, and see also 77-78; Ashtor, Ebrei cittadini 151-152. Jews also sold non-kasher wine in Venice in the sixteenth century: Jacoby, Les Juifs à Venise 202.

${ }^{45}$ LM no. 293. For cheese from that region, see above, p. 28.

46 Noiret, Documents 213-214. The grant was made by Marco Marcello, governor of Rethymno, who held that office in 1382: Elisabeth Santschi, Régestes des arrêts civils et des mémoriaux (13631399) des archives du duc de Crète (Bibliothèque de l'Institut hellénique d'études byzantines et post-byzantines de Venise 9, Venise 1976) 82, no.319. In Candia the leasing of storehouses to Jews outside their quarter was authorized in 1391 and 1406: see Maria Georgoponlon, Venice's Mediterranean Colonies. Architecture and Urbanism (Cambridge 2001) 200 and 334-335, n. 52.
} 
It is time to examine Jewish involvement in manufacture. When Benjamin of Tudela visited Constantinople around 1160, he noted three occupational groups within the Jewish community residing in the suburb of Pera: tanners, silk workers and merchants ${ }^{47}$. The Jewish neighborhood in the suburb of Pera was gutted by fire in 1203, and most surviving Jews established themselves in Constantinople proper. It is unclear whether they immediately and spontaneously settled in the region of Vlanga, or whether Michael VIII Palaeologus resettled the Jews in that area after 1261 in the framework of his policy to promote the city's economy. Jewish tanners are documented in that urban region around 1300. The neighboring harbor of Kontoskalion served as sewer for the dirty waters of the tanning ${ }^{48}$.

Jewish involvement in the tanning of hides in Constantinople increased in the following decades. This development was furthered by Venetian entrepreneurs. They engaged local craftsmen and apparently attracted others to process skins imported from the Black Sea, which after being tanned were shipped to Venice with added value. In order to further reduce the cost of the hides, Venice granted Venetian status to an unknown number of Jewish craftsmen, who thus enjoyed full exemption from imperial taxes. The cooperation between Venetian and Byzantine Jews in tanning, which also enabled evasion from imperial taxation, generated tension between Emperor Andronicus II and Venice from 1319 to 1324. Since only Jews are mentioned in that context, it is likely that they were dominant in tanning in Vlanga at that time. The Venetian Jews were compelled to resettle in the Venetian quarter in 1324 or shortly afterwards ${ }^{49}$.

The Jewish neighborhood of Vlanga survived until the Ottoman conquest of $1453^{50}$. Jewish tanners presumably pursued their activity in its midst. One of them appears in the account book of the Venetian merchant Giacomo Badoer, who resided in Constantinople from 1436 to 1440. In 1438 Elijah Chanazi delivered to him wool from 200 sheep hides, which he had tanned and were sent to Venice ${ }^{51}$. Later in the same year he tanned and bleached one batch of 272 and another of 200 hides, also shipped to Venice ${ }^{52}$. The Jew Elijah Dedimari, who traded in pepper and silk $^{53}$, stored in his warehouse 300 salted hides of castrated horses imported from

47 Marcus N. Adler (ed. and trans.), The Itinerary of Benjamin of Tudela (London 1907), Hebrew text 16-17, English trans. 14. New dating of his visit by David Jacoby, Benjamin of Tudela and his "Book of Travels", in: Klaus Herbers and Felicitas Schmieder (eds.), Venedig im Schnittpunkt der Kulturen. Außen- und Innensichten europäischer und nicht-europäischer Reisender im Vergleich (Venezia incrocio di culture. A confronto le percezioni dall interno e dall esterno di viaggiatori europei e non) (Roma 2008), in press.

48 David Jacoby, The Jewish Community of Constantinople from the Komnenan to the Palaiologan Period, in: Vizantijskij vremennik 55/2 (80) (1998) 31-40, repr. in Jacoby, Byzantium no. V.

49 David Jacoby, Les quartiers juifs de Constantinople à l'époque byzantine, in: Byzantion 37 (1967) 191-194, 196-207, repr. in David Jacoby, Société et démographie à Byzance et en Romanie latine (London 1975) no. II.

50 Ibid. 194-196.

51 Badoer 395 lines 2-9, 435 lines 14-18.

52 Badoer 434 lines 20-21, 582 lines 23-24.

53 Badoer 188 lines 32-36, 803 lines 20-21. 
the Black Sea for Badoer ${ }^{54}$. It is unclear whether he was involved in the tanning business.

Jewish tanners are also attested in several ports of the eastern Mediterranean under Venetian rule in the late medieval period. In Candia the tanneries were situated outside the western city gates along the Bay of Dermata or 'Bay of hides'55. The location of the Jewish quarter along that bay was clearly related to the exercise of tanning among Jews, attested in 1228, although there was no Jewish monopoly in the field ${ }^{56}$. The ritual slaughter of animals provided skins, and Jewish butchers acted as middlemen between the owners of herds and tanners, both Jewish and Christian. Yet Jews also bought dried and salted skins from Christian merchants and butchers, as in $1271^{57}$. In 1305 a Cretan Jew commissioned the construction of a mill for the grinding of various materials, including acorn cups providing tannin used in the tanning process ${ }^{58}$. The leather produced by Jews was not always of good quality, as attested in $1342^{59}$. Incidentally, in 1396-1398 the governor of Canea, Pietro Nani, bought a large quantity of skins at the slaughterhouse. Once they had been tanned he took advantage of his position to compel Jewish cobblers and other craftsmen to produce for him a substantial number of shoes, which he obviously intended to export. As a result, there was a shortage of shoes on the local market ${ }^{60}$. A contract of 1419 between two Jews of Candia provided for the tanning of skins by one of the partners ${ }^{61}$. Cretan Jews participated in the import of skins from the Turkish emirates of Asia Minor, which were tanned in Crete. In 1371 Salomon Astrigo entrusted 22 ducats to Elkanah son of Elkanah for the import of hides from Palatia (ancient Miletos), in the emirate of Menteshe ${ }^{62}$. In 1370 Shemaryah of Negroponte and Mordechay son of Yehudah de Medico of Candia

\footnotetext{
${ }^{54}$ Badoer 394 lines 2-3, 7-13, 17-21. The salting preserved the hides until the tanning was performed.

55 The name appears in 1352: Sally McKee (ed.), Wills from Late Medieval Crete, 1313-1420, vol. I (Washington, D. C. 1998) 247.

56 Ordinance of 1228 against the soaking of skins in the water of the ritual bath: Taqqanoth 8 , no. 15.

57 PS nos. 37, 72.

${ }^{58}$ Charalambos Gasparis, He ge kai oi agrotes sten mesaionike Krete, 13os-14os ai. (= Land and Peasants in Medieval Crete, $13^{\text {th }}-14^{\text {th }}$ c) (National Hellenic Research Foundation, Institute for Byzantine Research, Monographs 4, Athens 1997) 105.

59 Spyridon M. Theotokes (ed.), Thespismata tes benetikes gerousias, 1281-1385 (= Decrees of the Venetian Senate, 1281-1385) vol. I (Athens 1937) 225-226, no. 543.

60 ASV, Avvogaria di Comun, Raspe, V/II, fol. 49r, 16 March 1402. Nani was also accused of other misdeeds: Noiret, Documents 126-127. For his tenure of office, see ibid. 91-92.

${ }^{61}$ Chryssa Maltezou, Métiers et salaires en Crète vénitienne (XVe siècle), in: Byzantinische Forschungen 12 (1987) 329-330.

62 The deal concerned hides and not leather, as stated by Silvano Borsari, I movimenti del porto di Candia AA. 1369-1372 (Dal repertorio del notaio Giorgio Aymo), in: Università di Macerata, Annali della Facoltà di Lettere e Filosofia 30-31 (1997-1998) 335. On the import of hides from Asia Minor, see Elizabeth A. Zachariadou, Trade and Crusade. Venetian Crete and the Emirates of Menteshe and Aydin (1300-1415) (Library of the Hellenic Institute of Byzantine and Post-Byzantine Studies 11, Venice 1983) 264, s.v. skins.
} 
jointly traded in hides in Negroponte, the main city of the island of Euboea and an important transit port in which Venice had a quarter from 1211 onward $^{63}$. It is unclear whether they also dealt with tanning.

Jewish tanners were active in Coron and Modon, two ports of the southwestern Peloponnesus under Venetian rule from 1207 onward. In 1357 Moses son of David from Coron and another Jew, both residents of Candia, shipped skins to Coron and promised to pay for them after their return from that city ${ }^{64}$. The former resident of Coron must have been acquainted with local Jewish tanners there and assumed that tanning would be cheaper than in Candia. Fourteenth and fifteenthcentury Venetian ordinances and several travelers refer to tanners among the Jews living in a suburb of Modon ${ }^{65}$. In 1464 only Jewish tanners appear to have been available in the city ${ }^{66}$. Interestingly, Jews owning sheep and goats in the vicinity are attested in $1483^{67}$. It is unclear since when this was the case.

As noted earlier, Benjamin of Tudela encountered Jewish silk workers in Constantinople around 1160. High-grade silk manufacture collapsed in the city in the wake of its fall to the Latins in 1204, and the local silk workers moved to Asia Minor to pursue the exercise of their craft. Silk was later traded in Constantinople, yet the production of silk textiles was not revived until the Ottoman period ${ }^{68}$. There is some evidence suggesting the pursuit of silk manufacturing in Thessalonica in the fourteenth century. However, as noted above, we have no information regarding the economic activity of the city's Jews. Benjamin of Tudela was especially impressed by Jewish participation in the silk branch of Thebes, whether as weavers or tailors ${ }^{69}$. Thebes pursued the production of silk textiles in the thirteenth and fourteenth century $^{70}$. The continuous existence of the local Jewish community is attested in that period $^{71}$. However, whether Theban Jews participated then in local silk manufacture remains an open question, in view of the lack of evidence in that respect.

${ }^{63}$ Borsari, Ricchi e poveri 211, n. 3. On the quarter, see David Jacoby, La consolidation de la domination de Venise dans la ville de Négrepont (1205-1390): un aspect de sa politique coloniale, in: Chryssa A. Maltezou e Peter Schreiner (eds.), Bisanzio, Venezia e il mondo franco-greco (XIII-XV secolo) (Atti del Colloquio Internazionale organizzato nel centenario della nascita di Raymond Joseph Loenertz o. p., Venezia, 1-2 dicembre 2000) (Venezia 2002) 151-187.

${ }_{64}$ ZF no. 104; see also no. 120, which relates to the same journey.

65 Joshua Starr, Romania. The Jewries of the Levant after the Fourth Crusade (Paris 1949) 64, 66-67.

66 Sathas, Documents, vol. IV, 33-34.

${ }^{67}$ Ibid. 127

${ }^{68}$ David Jacoby, The Jews and the Silk Industry of Constantinople, in: Jacoby, Byzantium no. XI, 1-20; David Jacoby, The Silk Trade of Late Byzantine Constantinople, in: Sümer Atasoy (ed.), 550th Anniversary of the Istanbul University. International Byzantine and Ottoman Symposium (XVth century) (30-31 May 2003) (Istanbul 2004) 129-144.

${ }^{69}$ David Jacoby, Silk in Western Byzantium before the Fourth Crusade, in: Byzantinische Zeitschrift 84/85 (1991/1992) 466, 485-487, repr. in Jacoby, Trade no. VII.

70 David Jacoby, The Production of Silk Textiles in Latin Greece, in: Technognosia ste latinokratoumene Ellada (= Technology in Latin-Occupied Greece) (Athens 2000) 24-27, repr. in Jacoby, Commercial exchange no. XII.

71 Steven B. Bowman, The Jews of Byzantium, 1204-1453 (Tuscaloosa, Alabama 1985) 269-270, no. 60 a; 287 , no. $92 ; 296$, no. 108 note; 302-303, no. 117. 
In any event, some of them were acquainted with its sources of raw materials and its operation. This was certainly the case of Moses son of Shabbetai Galimidi, who in 1260-1263 left Thebes for Negroponte. His knowledge regarding silk was undoubtedly one of the reasons that prompted David Kalomiti, a rich merchant of Negroponte involved in silk transactions, to recruit him in his service. In the $1290 \mathrm{~s}$ Kalomiti entrusted Galimidi's sons with the collection of silk. It is unclear whether the reference is to raw material, silk textiles, or both, yet the operations must have taken place in Euboea and presumably also in neighboring territories. After David Kalomiti's death the relations between his sons and those of Galimidi soured, and some of these fled. It is not coincidental that one of them who had resided for some time in Corinth settled in Thebes after the earthquake of 1303, while another established himself in Andros, an island producing both raw silk and silk textiles in that period $^{72}$.

Jewish silk weaving was practiced in Candia on a modest scale. The purchase of small quantities of raw silk, in one case by a woman in 1373, suggests the domestic manufacture of small pieces such as girdles, hoods, veils and kerchiefs, similar to those produced by Jewish women in Modon in the late fifteenth century ${ }^{73}$. Yet there were also Jewish silk weavers who produced larger pieces ${ }^{74}$. Their sendals did not always meet the required quality standard, as reported in $1342^{75}$. Some Jews of Chios traded in silk, as attested in 1398 and in 1408, yet presumably on a small scale $^{76}$. In 1408 Aharon Lachano and Elijah Fogiano jointly operated a dyeing workshop in the city. Another Jewish dyer is recorded in Chios in $1456^{77}$.

Jews also practiced crafts other than tanning or silk weaving. A large number of cobblers worked in Candia in the fourteenth century, in addition to those attested in Canea around $1400^{78}$. In 1420 a Jewish mason and his Christian partner undertook to build a cistern for a Jewish physician in Candia ${ }^{79}$. A dagger was commissioned in 1394 from a blacksmith in Chios. Salomon Spagnoli and his son Joste

72 The case is reported in an anonymous and undated Hebrew letter, translated by Bowman, The Jews of Byzantium 234-240, no. 30. It has been discussed by several authors. I shall return to the issue and justify the dates mentioned here in a forthcoming study. On silk in Andros, see Jacoby, Silk in Western Byzantium 460-462; Jacoby, The Production of Silk Textiles 29.

73 For Crete: Borsari, Ricchi e poveri 220; for Modon: Starr, Romania 64.

74 Borsari, Ricchi e poveri 220-221.

75 Theotokes, Thespismata, vol. I, 226, no. 544.

76 Domenico Gioffrè, Atti rogati in Chio nella seconda metà del XIV secolo, in: Bulletin de l'Institut historique belge de Rome 34 (1962) 393; Michel Balard, La Romanie génoise (XII - début du $\mathrm{XV}^{\mathrm{e}}$ siècle) (Bibliothèque des Écoles françaises d'Athènes et de Rome 235, Rome 1978) 283.

77 Philip P. Argenti, The Occupation of Chios by the Genoese and their Administration of the Island, 1346-1566, vol. I (Cambridge 1958) 442-443, 647, and vol. III, 743-745, no.32. Fogiano is also recorded earlier as Foihano, yet without indication of his occupation: Paola Villa, Documenti sugli Ebrei a Chio nel 1394, in: Atti della Società Ligure di Storia Patria, n. s. 5 (79) (1965) 128, no. 4 .

78 Sally McKee, Uncommon Dominion. Venetian Crete and the Myth of Ethnic Purity (Philadelphia 2000) 94-95, and see above, p. 34.

79 Maltezou, Métiers et salaires 326. 
pursued the same occupation in Candia before 142480. A shipwright was active in Chios in $1456^{81}$. However, commerce and moneylending were clearly the main Jewish activities in the eastern Mediterranean of the late Middle Ages.

The range of goods Jews handled in local retail and wholesale trade extended beyond those mentioned above, as illustrated for Crete. In 1276 a Jew of Canea was robbed of wax, silk and grain while trading in the countryside to the east of the city along the bay of Suda ${ }^{82}$. Various sources mention women's finery, ironware, haired skins and tanned hides of domestic origin ${ }^{83}$, as well as imported textiles, from western woolens of rather modest quality to luxury velvet ${ }^{84}$. Diversity in local Jewish trade is also found elsewhere ${ }^{85}$.

The number of Jewish residents of Crete and Negroponte engaging in regional maritime trade appears to have been quite substantial by the last decades of the thirteenth century. The volume of their operations induced Venice to enhance its fiscal revenue by imposing a discriminatory tax of $5 \%$ upon goods imported or exported by its Jews, similar to that imposed upon foreigners. This tax, initially collected in Crete before 1290, was extended in that year to Negroponte, as well as to other Venetian colonies and outposts except for Tyre ${ }^{86}$. The Jews evaded that high rate by arriving at agreements with Venetian citizens, who presumably in return for a payment declared the formers' commodities as their own. In September 1290 Venice threatened those defrauding its treasury by that device with the confiscation of half their goods ${ }^{87}$.

The large geographic range and complex ramifications of Jewish maritime trade is amply illustrated from the second half of the thirteenth century onward. To the cases adduced above we may add a few others. In 1273 or somewhat later a Cretan Jew and his Christian associates returning from Thessalonica were robbed of their goods by pirates based in Monemvasia, the main port of the Byzantine Pelopon-

80 Gian Giacomo Musso, Gli Ebrei nel Levante genovese: ricerche di archivio, Berio - Bollettino bibliografico quadrimestriale 10/2 (1970) 19; ASV, Notai di Candia, b. 25, Giorgio Candachiti, fol. 224r.-v., deals with Joste Spagnoli's widow.

81 Argenti, The Occupation of Chios, vol. I, 443, 648.

82 Gottlieb L. Fr. Tafel und Georg M. Thomas (eds.), Urkunden zur älteren Handels- und Staatsgeschichte der Republik Venedig, vol.III (Wien 1856-1857) 257; dating by Gareth Morgan, The Venetian Claims Commission of 1278, in: Byzantinische Zeitschrift 69 (1976) 431, no. 137.

83 Taqqanoth 5, no.10, of 1228; Noiret, Documents 253-254, 269, respectively of 1416 and 1419.

${ }^{84}$ Silvano Borsari, Il mercato dei tessuti a Candia (1373-1375), in: Archivio veneto, $5^{\text {th }}$. ser. 143 (1994) 8, 13, 19-26.

${ }^{85}$ For details, see below.

${ }^{86}$ Roberto Cessi (ed.), Deliberazioni del Maggior Consiglio di Venezia, vol.III (Bologna 19311950) $274, \mathbb{\$} 94$. See also David Jacoby, Venice and the Venetian Jews in the Eastern Mediterranean, in: Gaetano Cozzi (ed.), Gli Ebrei e Venezia (secoli XIV-XVIII) (Milano 1987) 40, repr. in Jacoby, Studies no. X; David Jacoby, The Demographic Evolution of Euboea under Latin Rule, 1205-1470, in: Julian Chrysostomides, Charalambos Dendrinos, Jonathan Harris (eds.), The Greek Islands and the Sea (Proceedings of the First International Colloquium held at the Hellenic Institute, Royal Holloway, University of London, 21-22 September 2001) (Camberley, Surrey 2004) 160. For Tyre, see following note.

${ }^{87}$ Cessi, Deliberazioni, vol. III, 283, $\mathbb{} 124$. 
nesus ${ }^{88}$. In Negroponte the tax of $5 \%$ was presumably related to the export of raw silk, silk textiles, or both to Venice ${ }^{89}$. In 1286 a Jew from crusader Acre granted a piece of samite apparently bought in Negroponte and woolens to two Venetians in return for a loan ${ }^{90}$. Jewish merchants from the Aegean traded with Acre and Tyre before $1291^{91}$. Cretan Jews were regularly traveling to Alexandria before $1301^{92}$. They pursued that activity in the following decade, as implied by the complaints of the Dominican inquisitor Andreas Doto against them, voiced in 1314 or somewhat earlier and reproduced by the canonist Oldrado de Ponte ${ }^{93}$. Cretan Jews continued to do so even after Venice imposed a ban on trade with Egypt in 1323. Jewish and foreign merchants claimed that it did not apply to them since they paid the dues levied from aliens in Crete. In response Doge Giovanni Soranzo extended the ban to all the island's inhabitants in July $1324^{94}$. The resumption of direct trade between Venice and Egypt in 1345 reduced the role of Crete as intermediary until $1374^{95}$. Yet in 1357 a Jew and a Greek of Candia jointly exported to Damietta copper imported from an unknown western source ${ }^{96}$.

In 1318 Venice changed its policy in Negroponte and abolished the discriminatory rate it had imposed on Jewish maritime trade, in order to promote an increase in the number of its Jews in the city ${ }^{97}$. In 1321 two Jewish partners of Negroponte involved in regional maritime trade reported a loss of 1,544 hyperpers and a third Jew a loss of 42 hyperpers, both inflicted by Byzantine pirates operating in the Aegean ${ }^{98}$. There is no indication about the commodities they handled. On the other hand, around 1340 some Venetian Jews were trading in samites, most likely collecting them from weaving workshops in Euboea and Andros and exporting them to Venice. In 1340 a group of Jews who had recently obtained Venetian status complained that Jewish tax collectors in the service of the feudal lords of Euboea con-

88 Tafel und Thomas, Urkunden, vol. III, 160-161; dating by Morgan, The Venetian Claims Commission 429, no. 79 .

${ }^{89}$ On this export, see below, next paragraph.

90 David Jacoby, L'expansion occidentale dans le Levant: les Vénitiens à Acre dans la seconde moitié du treizième siècle, in: Journal of Medieval History 3 (1977) 248-249, repr. in Jacoby, Recherches no. VII.

${ }^{91}$ See previous note and for Tyre, above, n. 87.

92 As implied by BB no. 354 .

${ }^{3}$ David Jacoby, Venice, the Inquisition and the Jewish Communities of Crete in the early $14^{\text {th }}$ Century, in: Studi veneziani 12 (1970) 128-129, 138-141, repr. in Jacoby, Recherches no. IX. Translation of Doto's arguments by Norman Zacour, Jews and Saracens in the Consilia of Oldradus de Ponte (Pontifical Institute of Mediaeval Studies, Studies and Texts 100, Toronto 1990) 36-37.

${ }^{94}$ David Jacoby, Creta e Venezia nel contesto economico del Mediterraneo orientale sino alla metà del Quattrocento, in: Gherardo Ortalli (ed.), Venezia e Creta (Atti del Convegno internazionale di studi, Iraklion-Chanià, 30 settembre - 5 ottobre 1997) (Venezia 1998) 97-98.

95 Ibid. 99.

${ }_{96}$ ZF 67, no. 91 .

${ }^{97}$ Jacoby, The Demographic Evolution of Euboea 161. The rate was maintained in Crete: see above, n. 94 .

98 Thomas, Diplomatarium, vol. I, 183-184. 
tinued to collect from them the trade tax on behalf of these lords. They requested Venice to intervene in order to ensure them the same fiscal exemption as that enjoyed by the Judei antiqui of Venice. Leo Psoma of Negroponte presented the petition in Venice, where he must have been involved in trade ${ }^{99}$. Some twenty years later he was importing raw silk to Venice on a large scale. In 1361 the verdict inflicting upon him the huge fine of 4,000 hyperpers or more than 1,000 ducats for illegal dealings was quashed and he was exceptionally allowed to transfer that sum or its equivalent in goods on board a state galley sailing to Negroponte. In 1440 the Venetian Senate stressed the importance of the state revenue deriving from Jewish trade in Negroponte. A petition submitted by the Jews of Negroponte in 1452 mentions commercial journeys to Genoese Chios, Turkish Asia Minor, Rhodes, ruled by the Hospitallers, and other destinations ${ }^{100}$.

We have already noted some commercial operations of Cretan Jews directed toward Constantinople. These operations were undoubtedly furthered by the presence of Venetian Jews established in the Venetian quarter of the Byzantine capital, among them immigrants from Crete who retained links with their family in the island ${ }^{101}$. In 1350 the Venetian Jew David Yalomati, who resided in Constantinople, gave power of attorney to Samuel son of Samson to collect in his name in Crete money owed by Moyse Casani, a resident of Candia, transfer it to David's son Elijah, who obviously would be there, and appear before the Venetian authorities in the island if necessary ${ }^{102}$.

As noted above, Jewish trade between Crete and Venice was not limited to kasher goods. A decree issued in 1402 exceptionally allowed some Jews undoubtedly living in Venetian colonies to send money from Venice to Corfu, Coron, Modon and Crete on board state galleys in return for a fee of two percent ${ }^{103}$. A Jewish merchant and his wife from Candia resided in Venice some time before $1414^{104}$. Isaiah son of Hayyim was a Cretan merchant who often traveled to that city. In Alexandria Elijah Capsali gave him power of attorney in 1420 to obtain in Venice a loan of 130 ducats and transfer the sum to the Egyptian port or to Candia ${ }^{105}$. In 1422 he entrusted the same Jew, another one of Candia and a resident of Venice to

99 Ed. by François-Xavier Leduc (ed.), Venezia - Senato. Deliberazioni miste, Registre XIX (13401341) (Istituto veneto di scienze, lettere ed arti, Venezia - Senato. Deliberazioni miste VI, Venise 2004) 18, no.36. See Jacoby, The Demographic Evolution of Euboea 161-162.

100 Ibid. 164-165.

101 Jacoby, Les quartiers juifs de Constantinople 205-214.

102 Angeliki E. Laiou, Un notaire vénitien à Constantinople: Antonio Bresciano et le commerce international en 1350, in: Michel Balard, Angeliki E. Laiou, Catherine Otten-Froux, Les Italiens à Byzance (Byzantina Sorbonensia 6, Paris 1987) 125-126, no. 27.

103 Jacoby, Venice and the Venetian Jews 48-49 and 57, n. 81.

104 ASV, Avvogaria di Comun, Miscellanea civil, b. 31, fasc. 27, ed. by David Jacoby, Inquisition and Converts in Candia and Negroponte in the $14^{\text {th }}$ and $15^{\text {th }}$ Centuries, in: Sefunoth, Annual for Research on the Jewish Communities in the East 8 (1964) 314-316, no.2, with commentary ibid. 308-310 [Hebrew].

105 Ed. by Verlinden, Marchands chrétiens et juifs 53. 
obtain for him in that city full Venetian citizenship ${ }^{106}$. In 1428 a Jew of Candia engaged a Majorcan Jew as servant for the duration of his round-trip to Venice ${ }^{107}$.

Jews also conducted local, regional and long-distance trade in and around Genoese Chios. Moses Cohen together with some Jews of Pera imported foodstuffs such as grain, flour, chickpeas and figs, the dyestuff orchil, as well as skins, cloth, carpets and blankets from the island of Mytilene (Lesbos) to Chios ${ }^{108}$. Jews bought imported goods, such as silks in 1408, pearls and precious stones in 1413, and fustians in $1414^{109}$. In 1450 or somewhat earlier the Christian Lazarus Catalanus entrusted a Jew with the purchase of grain ${ }^{110}$. Elijah Calaihi traded in Pera before $1394^{111}$.

It is noteworthy that in Chios Jews handled two commodities, grain and mastic, that were closely supervised by the local authorities. The Officium provisionis, apparently composed of wealthy residents, namely two Latins, two Greeks and one Jew, was responsible for the supply of grain to Chios. It concluded agreements with merchants undertaking to import specific quantities of grain from Apulia, Sicily, or Phocea on the coast of Asia Minor, found the necessary capital to finance the deals, and guaranteed minimum prices it would pay ${ }^{112}$. In 1404 the Jew Benjamin was member of that office, and the Jew Nathan undertook to bring in the same year 200 modia grains to Chios ${ }^{113}$. The gross sale of mastic was a monopoly of the Maona of Chios, the body composed of Genoese settlers governing the island ${ }^{114}$. In 1386 this institution promised mastic to a Jew in return for a loan. In 1394 the Jew ceded his right to obtain the remainder of the mastic to two Genoese, who were to sell it in Cyprus, Damascus or Alexandria ${ }^{115}$. In 1403 Elijah Cohen concluded in Chios a contract with a Turk of Bursa by which he undertook to deliver him thirteen cases of mastic either in Pergamon or in Iasmati (AyiasmatinHagiasmatin, presently Altun-ova), situated on the coast of Asia Minor between Chios and Mytilene ${ }^{116}$. All three localities were then under Ottoman rule.

106 Ed. by Ashtor, Ebrei cittadini 147-148, and commentary ibid. 152-153. Ashtor was completely mistaken about the issue of Jews and Venetian citizenship, for which see Jacoby, Venice and the Venetian Jews 34-38.

107 Ed. by David Jacoby, Quelques aspects de la vie juive en Crète dans la première moitié du XV siècle. Actes du Troisième Congrès international d'études crétoises (Rethymnon 1971) vol.II (Athènes 1974) 115, n. 39, and commentary ibid. 114-115, repr. in Jacoby, Recherches no.X.

108 Gioffrè, Atti rogati in Chio 348-349, 389-390.

109 Musso, Gli Ebrei 16.

110 Argenti, The Occupation of Chios, vol. III, 629, no. 215.

111 Villa, Documenti sugli Ebrei 126-127, no.3.

112 On the operation of the office, see Balard, La Romanie génoise 388-389, 392, and the following note.

113 Paola Piana Toniolo (ed.), Notai genovesi in Oltremare. Atti rogati a Chio da Gregorio Panissaro (1403-1405) (Accademia Ligure di Scienze e Lettere, Serie Fonti 2, Genova 1995) 176-177, no. 126; and 180-181, no. 131.

114 Michel Balard, Le mastic de Chio, monopole génois (XIV ${ }^{\mathrm{e}}-\mathrm{XVI}^{\mathrm{e}}$ s.), in: Raoul Curiel et Rika Gyselen (eds.), Itinéraires d'Orient. Hommages à Claude Cahen (Bures-sur-Yvette 1994) 223-228.

115 Villa, Documenti sugli Ebrei 138-144, nos. 9-10.

116 Piana Toniolo, Notai genovesi 105-106, nos. 52-53. My thanks to Elizabeth Zachariadou for identifying and locating Iasmati. 
The Jews residing in Constantinople engaged in regional maritime commerce, yet they appear to have been primarily involved in local trade. Two Jews bought respectively a garment and a piece of cotton cloth from a Genoese merchant in Pera around $1390^{117}$. In 1389 the physician Baronus living in that suburb willed a quarter of his movable wealth to his son-in-law Ismael from Chios, also a physician, yet on condition that his investments would be limited to trade from the island of Tenedos northward and in the Black Sea ${ }^{118}$. In 1394 Shemaryah, a nephew or grandson of Baronus, and a Jew of Candia, settled their business accounts in Chios $^{119}$. In 1398 two Jews of Pera traded in Mytilene and Chios ${ }^{120}$. In 1437-1438 Baron, most likely a grandson of the physician Baronus mentioned above, acted jointly with magister Elijah, who appears to have been a Venetian Jew, buying silken veils from the Venetian Giacomo Badoer ${ }^{121}$. The two, as well as Barona, surely a relative of Baron, appear in 1443 among the creditors of Gabriele Catacalo, a Greek of Candia who served as notary and interpreter at the court of the Venetian bailo in Constantinople between 1434 and 1449. The verdict issued by the bailo Marino Soranzo in 1443 was transcribed ten years later in Pera at the request of a Genoese creditor ${ }^{122}$. The cooperation of Venetian Jews with other merchants in Constantinople is illustrated in 1418. Emperor Manuel II accused Venetian citizens, subjects and Jews of defrauding the imperial treasury by declaring at the customs goods belonging to imperial subjects and to Turks as their own ${ }^{123}$.

The Venetian Giacomo Badoer conducted business with thirty Jews during his stay in Constantinople from 1436 to 1440. Most transactions involved Jews selling high-grade silk from the region of the Caspian Sea, requested by silk weavers in Venice, and purchasing western textiles or bartering the silk for these goods. In one

117 Michel Balard, Péra au XIVe siècle: Documents notariés des archives de Gênes, in: Balard, Laiou, Otten-Froux, Les Italiens à Byzance 63, no.139. Another customer, Lodixio Portonario, is attested in documents of 1389 and 1390 and thus provides an approximate date for the leaf from the merchant's account book on which the Jews are recorded: ibid. 31, no. 59; 34, no.71; and 42, no. 102.

118 Ibid. 35, no.75, and see also no. 74. Similar restrictions appear in charters drafted in Black Sea ports limiting trade to the region extending as far as Abydos in the Dardanelles: Nicolas Oikonomidès, Hommes d'affaires grecs et latins à Constantinople (XIII $-\mathrm{XV}^{\mathrm{e}}$ siècles) (Montréal-Paris 1979) 39.

119 Villa, Documenti sugli Ebrei 148-149 no. 12.

120 See above, note 76.

121 Joint operations in Badoer, 174 lines 17, 21; 219 lines 24-25; 287 lines 10-11; 340 lines 25-26, 28; 348 lines 18-20; 349 lines 18-19; 368 lines 28; 409 lines 2-3; 466 lines 4-5. Magister Elijah was a relative of a Venetian Jewess, mentioned in a letter of the bailo Pietro Contarini written in 1424: ed. by Jacoby, Les quartiers juifs de Constantinople 224, no.II.

122 Ausilia Roccatagliata, Notai genovesi in oltremare. Atti rogati a Pera (1453), in: Atti della Società ligure di Storia patria, n.s. 39 (CXIII) (1999) 136-142, no.11. For the tenure of office of Catacalo, see Chryssa Maltezou, O thesmos tou en Konstantinoupolei Benetou bailou (1268-1453) $=$ The Institution of the Venetian Bailo in Constantinople, 1268-1453) (Athens 1970) 184 no. 33; 186-188 no. 37; 206 no. 53; 207-209 no. 58.

123 Julian Chrysostomides, Venetian Commercial Privileges under the Palaeologi, in: Studi veneziani 12 (1970) 354-355, no. 19. 
case Daniel de Anastaxo sold more than 1,385 pounds of silk worth 6,237 hyperpers, which he exchanged for silk cloth, silken veils and woolens of various qualities ${ }^{124}$. Several Jews bought western gold thread used in embroidery ${ }^{125}$. These commodities were partly intended for re-export to Ottoman territories and to Black Sea ports. Such was certainly the case of the woolens bought in 1438 by a Jew from Adrianople/Edirne, the Ottoman capital at that time ${ }^{126}$. There was a large demand for Italian silks and woolens among the Ottoman elite ${ }^{127}$. Yet Jews also handled other commodities. Wax imported from the Black Sea, especially from the region of Zagora in Bulgaria, was shipped to Venice on a large scale ${ }^{128}$. While two local Jews sold wax bought from importers ${ }^{129}$, Jacob of Sofia arrived in 1438 in Constantinople with a large consignment of wax that he sold directly to Venetian merchants, in one case in exchange for woolens from Maiorca ${ }^{130}$. Elijah Flaflama and Elijah Dedimari bought pepper imported from Caffa in the Crimea, which they sold to Venetians ${ }^{131}$. On the other hand, the Jew Zechariah purchased tin brought from Venice ${ }^{132}$.

Jewish trade in the eastern Mediterranean was furthered by two factors: Jewish mobility across political and cultural boundaries, more extensive than for other ethnic, religious or cultural groups, and linguistic aptitudes. Negroponte attracted Jewish immigrants from the Greek mainland and Crete in the thirteenth and fourteenth century, yet there was also emigration from Negroponte to Candia. Spanish and Oriental Jews appear in that city by the mid-fourteenth century, as well as in Constantinople. Cretan Jews established in Constantinople and Alexandria have already been mentioned ${ }^{133}$. Some Jews from Genoese Chios settled in Pera ${ }^{134}$. Connections between family members and partners dispersed throughout the eastern Mediterranean and beyond were an important asset in business.

The use of Hebrew facilitated connections and transactions between Jews living in different cultural milieus. The extensive business of Cretan Jews in Alexandria in the 1420s was undoubtedly furthered by their meeting with Jews from other Christian and from Muslim countries in the funduq or fondaco for foreign Jews, attested in $1405^{135}$. In addition, migration across the Mediterranean created polyglot Jewish communities. Polyglot Jews acted as middlemen and interpreters, functions that enabled the collection of precious commercial information. Jews appear as official

124 Badoer, 792 lines 1-18, 793 lines 2-9.

125 Badoer, 197 lines 4-5,10-11,15-18, 21-22; 229 lines 25-31, 35-37.

126 Badoer, 511 lines 11-13.

127 Jacoby, The Silk Trade of Late Byzantine Constantinople 134-140, 142-144.

128 Giovanni Bertelè, Il Libro dei conti di Giacomo Badoer (Costantinipoli 1436-1440). Complemento e indici (Padova 2002) 161-163, s. v. Zera.

129 Badoer 30 lines 27-29; 55 lines 18-20; 97 lines 43-44; 170 lines 2-4.

130 Badoer 740 lines 20-38; 743 lines 37-40; 745 lines 12-13.

131 Badoer 745 line 25; 759 line 11; 760 lines 2-5, 18-19.

132 Badoer 74 lines 25-27; 75 lines 18-19.

133 Jacoby, The Demographic Evolution of Euboea 159-162, 165-167; Jacoby, Quelques aspects 108-112.

134 See below, note 154 .

135 See Ashtor, New Data 81. The authorities would not have established a funduq for local Jews. 
and private middlemen in Crete until 1433, when Venice prohibited their employment in that capacity in transactions between Christians ${ }^{136}$. On the other hand, private Jewish brokers are attested in fifteenth-century Constantinople ${ }^{137}$, and official ones operated in Alexandria ${ }^{138}$. In this city the Mamluk authorities and some foreign consuls employed Jews as official interpreters ${ }^{139}$.

Jewish moneylending is often attested by notarial and official documents, since it generated lawsuits, legislation and taxation. However, it is important to note that its nature differed widely. We have already mentioned advance payments for the delivery of cheese, wine and grain, as well as loans in kind, such as wine, cheese and grain, the latter to be sown in return for the entire product of the harvest to be delivered at the creditor's home ${ }^{140}$. Jewish retailers in Rethymno and undoubtedly also in other Cretan cities sold various commodities on credit ${ }^{141}$. All these transactions, which often resulted in heavy indebtedness among peasants, were prohibited in $1393^{142}$. From the thirteenth century onward many urban residents in Crete, including Venetian fiefholders, prominent Greeks, as well as some of the duke's councilors and members of their staff took consumption loans or bought goods on credit $^{143}$. The treaty concluded by the Cretan archon Alexios Kallergis with Venice in 1299 contains a provision allowing Jews to reside wherever they wish ${ }^{144}$. His intervention on their behalf was presumably related to loans obtained from them during his rebellion. In the years 1360-1381 Yehudah de Medego son of Elijah granted in Candia loans to members of the Venetian and Greek aristocracy of Crete, 1,440 hyperpers in one case and 8,038 hyperpers in another ${ }^{145}$. In 1408 Cassani of Candia loaned 500 ducats to the local authorities for the equipment of the galley of Crete ${ }^{146}$. David Kalomiti lent money to the feudal lords of Euboea in the second half of the thirteenth century, as implied by the Hebrew letter referring to

136 Jacoby, Venice, the Inquisition and the Jewish Communities 128-138; Noiret, Documents 359361.

137 Giovanni Bertelè, Il Libro dei conti di Giacomo Badoer 173, s.v. Cain; 196-197, s.v. Pulixoto; 198 , s.v. Samaria zudio sanser.

138 Verlinden, Marchands chrétiens et juifs 69; Ashtor, New Data 89.

139 Ibid. 88-89.

140 Grain: LM no.358. On loans in wine and cheese, see above, p. 32.

141 See above, note 24.

142 See above, p. 29.

${ }^{143}$ See below, p. 45; Johannes Jegerlehner (ed.), Beiträge zur Verwaltungsgeschichte Kandias im XIV.Jahrhunderts, in: Byzantinische Zeitschrift 13 (1904) 450, \$64: prohibition of 1369 regarding officials.

${ }_{144}$ Ed. by Konstantinos Mertzios, He syntheke Eneton-Kalerge kai oi sunodeuontes auten katalologoi (= The Venetian-Kallergis Treaty and the Adjunct Lists), in: Kretika Chronika 3 (1949) 272, $\$ 22$. On the long rebellion of Kallergis and the treaty, see Silvano Borsari, Il dominio veneziano a Creta nel XIII secolo (Napoli 1963) 51-66.

145 Borsari, Ricchi e poveri 212 and n. 4.

146 Freddy Thiriet, La Romanie vénitienne au Moyen Âge. Le développement et l'exploitation du domaine colonial vénitien (XII $-\mathrm{XV}^{\mathrm{e}}$ siècles) (Bibliothèque des Écoles françaises d'Athènes et de Rome 193, Paris 1959) 408. 
him, and possibly also to the Venetian authorities in Negroponte ${ }^{147}$. It is likely that David of Negroponte was granted Venetian status in 1268 after loaning a substantial sum to these same authorities ${ }^{148}$. Local Jews lent money to prominent men in the Catalan Duchy of Athens around 1370, and in the 1390s to the count of Cephalonia, Carlo Tocco, who had taken hold of Corinth, in this case in return for jewels as security ${ }^{149}$. In February 1389 two Jews of Chios jointly loaned 2,669 ducats for about two and a half months to the Maona of Chios ${ }^{150}$. Geronimo da Camoglio, bishop of Chios, claimed in the 1470s that his predecessors had been compelled to obtain loans burdened with heavy interest from Jews, since the Maona had failed to transfer to them the entire yearly amount it had promised ${ }^{151}$.

Credit was an indispensable tool in local and especially regional trade. Jews around the eastern Mediterranean granted and received commercial, exchange and maritime loans and concluded unilateral collegancia contracts binding a sedentary investor to a traveling manager, who obtained one third of the profit. In 1301 the Jew Belus concluded two contracts by which Matteo Beaqua, like him a resident of Candia, invested capital in a societas terre for trade in Crete during three months and in a cambium maritimum with repayment of the loan in Alexandria in local currency ${ }^{152}$. Moses son of Yehudah of Candia granted 31 maritime loans totaling 1,002 hyperpers with interest within the second half of 1369 , the rate of interest varying according to destination and the presumed length of the roundtrip, which included ports of the Aegean, Cyprus, Alexandria, Constantinople, Venice and Pisa. Within the years 1369-1372 he extended such loans amounting to more than 7,700 hyperpers ${ }^{153}$. In 1391 the Jewish physician Yishmael of Chios granted in Pera a commercial loan to Francesco Giustiniani de Campis, which had not been repaid by $1394^{154}$. In that year the Jew Raffael Catalano received in Chios a loan of 350 ducats from Giovanni Giustiniani, who acted on behalf of Domenico Cataneo of Genoa ${ }^{155}$. In 1400 the patriarchal court in Constantinople dealt with a commercial loan granted by a Jew to a Greek in the previous year ${ }^{156}$. In 1418 Elijah of Rethymno loaned in Candia 2,200 hyperpers to Niccolò Taiapetra of that city, a sum not yet repaid in $1421^{157}$, and in 1414 Lazar Todescho granted 1,082 hyperpers to Bernardo Balbi and his brothers,

\footnotetext{
147 See above, n. 72.

148 Jacoby, The Demographic Evolution of Euboea 160-161.

149 Ibid. 164.

150 Enrico Basso (ed.), Notai genovesi in Oltremare. Atti rogati a Chio da Giuliano de Canella (2 Novembre 1380-31 Marzo 1381) (Accademia Ligure di Scienze e Lettere [Serie Fonti] 1, Athena 1993) 101-102 no. 45.

151 Argenti, The Occupation of Chios, vol. I, 655. Geronimo, bishop from 1470, negotiated a new settlement with the Maona after the intervention of Pope Sixtus IV, elected in 1471.

152 BB, nos. 353-354.

153 Borsari, Ricchi e poveri 213-214; Borsari, I movimenti del porto di Candia 327-329, 338.

154 Ed. by Villa, Documenti sugli Ebrei 145-147 no. 11.

155 Ibid. $127-129$ no. 4.

156 Franz Miklosich et Joseph Müller (eds.), Acta et diplomata graeca medii aevi sacra et profana, vol. II (Wien 1860-1890) 313-314 no. DXXX.

157 Ed. by Verlinden, Marchands chrétiens et juifs 61-62.
} 
residents of Venice ${ }^{158}$. The will of Bartolomeo Zane de Visdanelis, drafted in Patras in 1430, provided for the reimbursement of two commercial loans granted by Jews. One of the creditors was to obtain 1,000 pounds of iron, to be brought from Lepanto, in addition to a sum of money, the other a sum corresponding to the debt recorded in the testator's account book ${ }^{159}$. By the early fifteenth century the Jews of Rethymno were investing money in colleganze on a large scale, besides exporting cheese and wine to Egypt. In 1412 prominent Latin residents of the city pointed to the considerable profit the Jews enjoyed from these investments, in addition to moneylending ${ }^{160}$. We may safely assume that this was also the case in Candia.

Jews conducted maritime trade with the assistance of agents or acted as agents and operated as partners in joint ventures. Jews appear as agents of Jews in Alexandria in 1428 and in Constantinople in 1437161. Around 1300 some Cretan Jews served as agents or partners of Christian Catalans on their way with western woolens to Cyprus, Rhodes, the Levant and Egypt. Partnerships between Cretan Jews and Venetian citizens residing in Venice or elsewhere, some of them belonging to the city's social elite, are attested in the first half of the fifteenth century. They involved the transfer of capital between Venice, Venetian colonies and Venetian outposts $^{162}$. In 1394 Elisha of Chios jointly with several Latins insured the cargo on board the ship of Bernabò Dentuto sailing to Altoluogo (also called Theologo, ancient Ephesos), in the emirate of Aydin ${ }^{163}$. In 1404 Elijah Cohen of Chios contributed 300 ducats to a joint venture with a capital of 8,800 ducats involving a sailing to Sicily and trade in that island ${ }^{164}$.

Credit operations resulted in various cases in the transfer of rural land and dependent peasants into Jewish hands as acquisition from insolvent debtors, whether temporarily as security for loans or permanently, at least in principle. In the second half of the thirteenth century David Kallomiti of Negroponte had fields and vineyards in Euboea ${ }^{165}$. In 1370 four rich Jews of Negroponte held rural property belonging to the Latin patriarchate of Constantinople ${ }^{166}$. In 1402 Venice, alarmed by the increase in Jewish rural property in Euboea, ordered the Jews to relinquish all assets located outside the old Jewish quarter of Negroponte and prohibited further acquisitions ${ }^{167}$. Verdicts issued by the dukes of Crete in 1364 and 1372 illustrate Venice's strong opposition to the transfer of a specific category of property to Jews,

158 ASV, Notai di Candia, b. 26, Gasparino Cocco, fol. 88v.

159 Ed. by Ernst Gerland, Neue Quellen zur Geschichte des lateinischen Erzbistums Patras (Leipzig 1903) 213 and 215 no. 17.

160 Noiret, Documents 213. See also above, p. 44.

161 See respectively above, n. 41, and Badoer 179 lines 15-16, 188 lines 32, 40.

162 Jacoby, Venice and the Venetian Jews 48.

163 Villa, Documenti sugli Ebrei 149-151 no. 13.

164 Piana Toniolo, Notai genovesi 118-119 no. 65.

165 See above, note 72.

166 Borsari, Ricchi e poveri 219-220. In 1314 Pope Clement V united the functions of bishop of Negroponte and Latin patriarch of Constantinople, whose seat was since then in Negroponte: Giorgio Fedalto, La chiesa latina in Oriente, vol. I (Verona $\left.{ }^{2} 1981\right)$ 281, 443.

167 Sathas, Documents, vol. II, 83-84 no.303; also in Noiret, Documents 131-133. 
namely, fiefs and sergeantries entailing military service granted by the state to Latins and some Greeks ${ }^{168}$. A verdict of 1414 ordered the immediate sale of real estate serving as collateral to a loan to Venetians capable of performing the required service ${ }^{169}$. In 1423 Venice issued a general ban on Jewish acquisitions of property outside the Jewish quarters in its overseas territories, and enjoined the Jews to sell the property they held within two years ${ }^{170}$. The decree was repeated in the following year with additional clauses to prevent transgressions ${ }^{171}$. Jews nevertheless continued to acquire property outside their quarters. Thus in 1450 the Jew Theodoro Cresto of Candia obtained a vineyard in the region of Bonifacio in southern Crete from a Greek peasant, as partial repayment of a loan ${ }^{172}$.

There was apparently no limitation to Jewish rural property in the eastern Mediterranean outside the Venetian territories. In 1394 a Genoese judge in Chios allocated to Elijah Cohen a sum of money, a fruit garden, a field and part of a vineyard in compensation for a loan to Niccolò Tilano ${ }^{173}$. In 1398 the Jewess Ihera Melicha of Chios owned fruit gardens in the city's suburb and vicinity and other vineyards in the countryside ${ }^{174}$. Jews must have been eager to obtain rural land with their villeins as security for loans, for such lands' yield of revenue and, more importantly, for enabling close supervision over the production of kosher produce. Not surprisingly, therefore, Jews also leased land, like Salomon son of Abraham, a resident of Patras in the Peloponnesus, who for many years before 1436 had held a plot of rural land turned into a garden in the city's vicinity ${ }^{175}$.

This brief survey is far from exhaustive. It covers only some major fields of Jewish economic activity and fails to deal extensively with various Jewish occupations such as those of rabbis, physicians, pharmacists, lawyers, teachers and scribes, as well as communal and ritual officers, which were often combined with trade and moneylending. Shopkeepers, servants and seasonal workers have been mentioned in passing only. The picture emerging from the evidence, overwhelmingly found in Venetian and Genoese sources, is necessarily fragmented and biased. It nevertheless allows some conclusions.

168 Maria K. Chairete, Anekdota benetika eggrafa peri ton Ebraion en Krete (= Unpublished Venetian Documents regarding the Jews in Crete), in: Epeteris Etaireas byzantinon spoudon 33 (1964) 171-179, nos. 1-5: exceptis tamen feudis que remanentur in dispositione ducalis dominii and similar formulations. On the illegal transfer of a fief to a Jew in 1341, see McKee, Uncommon Dominion 71 and 184-187.

169 Chairete, Anekdota benetika eggrafa 180-182 no.6.

170 Noiret, Documents 297-298. For Corfu, see Jacoby, Venice and the Venetian Jews 53, n. 26, and the study by Reinhold Mueller in this volume.

171 Eliyabu Ashtor, Gli inizi della Comunità ebraica a Venezia, in: La Rassegna Mensile di Israel 44 (1978) 689-690, repr. in idem, The Jews and the Mediterranean Economy, Tenth to Fifteenth Centuries (London 1983) n.IV.

172 ASV, Notai di Candia, b. 2, Francesco Avonal, fol. 3v. See also Jacoby, Venice and the Venetian Jews 37-38.

173 Villa, Documenti sugli Ebrei 122-126, no. 2.

174 Gioffrè, Atti rogati in Chio 379-381.

175 Gerland, Neue Quellen 218-220, no. 19. 
Jews operated within two distinct, though partly overlapping and strongly interwoven economic networks. Indeed, the internal network dealing with Jewish goods was a closed circuit, yet required close cooperation with non-Jews. It largely, though not entirely conformed to the features of the broader eastern Mediterranean economy within which it was integrated with respect to capital investment, business patterns, production, transportation, distribution and sale. It was also similarly subject to state regulation and taxation. However, the geographic range and orientations of its distribution pattern, especially for wine, were far more extensive than for non-kasher commodities since they were determined by the wide Jewish dispersion in the Mediterranean region and beyond. Some Jewish communities could not ensure the production of kasher food and wine, either because of their small size, unfavorable economic conditions in their region, or the absence of a rabbinical authority sanctioning the fitness of the commodities. As a result, these communities and scattered individual families depended upon provisioning from larger or well-supplied centers. However, the diffusion of kasher goods was also determined by a demand for alternative qualities, as for instance wine in Constantinople ${ }^{176}$. The three main ports of destination of Cretan products in the eastern Mediterranean acted as distribution centers. Constantinople supplied Jews in neighboring European and Asian territories and around the Black Sea ${ }^{177}$. Alexandria acted similarly with respect to provincial cities in Egypt ${ }^{178}$, and Venice to northeastern Italy. Kasher commodities were clearly more expensive than others, as a result of the added cost of supervision, the special arrangements related to it, and a less competitive market than for other goods. In 1422 the wholesale price of a cask of Cretan wine in Alexandria was 12 ducats, whereas that of kasher wine was $141 / 2$ ducats. In addition, the profit margin for the kasher wine was undoubtedly much larger, since its retail sale was expected to yield at least 23 ducats per cask ${ }^{179}$.

There was no economic activity exclusively carried out by Jews, expect for ritual and communal functions, no legal impediments to the exercise of occupations, nor was any occupation imposed upon them, as often argued with respect to tanning in Byzantium. The Jews were firmly integrated within the production, manufacture and trade networks of Byzantium and Latin Romania, though to varying degrees determined by local and regional conditions. Their financial and actual involvement in maritime trade appears to have been more important than generally assumed, yet its extent and volume was restricted by two factors. Jews were entirely barred from the lucrative trans-Mediterranean trade in precious commodities, monopolized by the Venetian and Genoese social elites, and could only participate in it at the local or intermediate level, as illustrated for Crete and Constantinople. In addition, Jews lacked transportation facilities of their own, were reluctant to invest

\footnotetext{
176 See above, pp. 30-31.

177 Wine exported from Candia reached Tana at the mouth of the river Don: Pegolotti, La pratica

24: We may safely assume a similar transfer of kasher wine.

178 As attested for Sicilian cheese: Goitein, A Mediterranean Society, vol. IV, 251-252.

179 Ashtor, New Data 95-96, no. II.
} 
in them, and only seldom acquired a share in small vessels ${ }^{180}$. As a result, they were totally absent from the large-scale trade and transportation of grain, alum and cotton across the Mediterranean.

Some developments were specific to the Jewish communities in the Venetian colonies. The growing fiscal burden upon them in the fourteenth and fifteenth centuries limited the capital available for investment in trade ${ }^{181}$, and the restrictions on the acquisition of real estate undoubtedly enhanced the involvement of Jews in moneylending. In terms of capital, this appears to have been the largest sector of Jewish economic activity in Venetian Crete.

180 The religious restrictions on sailing on Sabbath and Jewish holidays were clearly an indirect, though important factor in that respect and also account for the absence of Jewish sailors.

181 Thiriet, La Romanie vénitienne 406-407; Jacoby, Venice and the Venetian Jews 40-41. 